\title{
Europejskie ramy prawne edukacji międzykulturowej i dialogu międzykulturowego
}

Streszczenie: Rozpatrywanie kwestii edukacji międzykulturowej i dialogu międzykulturowego w kontekście prawnym i instytucjonalnym pozwala ustalić, jaka jest oficjalna polityka danego państwa lub organizacji międzynarodowej oraz dominujący dyskurs w odniesieniu do tzw. mniejszości. Autor koncentruje się na działalności Rady Europy, której rola w promowaniu edukacji międzykulturowej i dialogu międzykulturowego jest kluczowa. Rada Europy wypracowała wiele instrumentów (konwencje, rekomendacje, rezolucje, deklaracje, „karty”), które podejmują kwestie różnorodności kulturowej i pluralizmu oraz promują wizję społeczeństw bardziej demokratycznych, w których filozofia praw człowieka umożliwia transcendencję partykularyzmów lokalnych. Szczególną uwagę zwrócono na Biata Księgę w sprawie dialogu międzynarodowego "Żyć wspólnie jako równi w godności", uznawaną aktualnie za dokument referencyjny w kwestiach demokratycznego zarządzania różnorodnością. Podkreślono znaczenie Europejskiej Konwencji Praw Człowieka i Podstawowych Wolności oraz orzecznictwa Europejskiego Trybunału Praw Człowieka w definiowaniu i generowaniu norm determinujących prawne i polityczne wymiary dialogu międzykulturowego.

Słowa kluczowe: edukacja międzykulturowa, dialog międzykulturowy, Rada Europy, Biała Księga w sprawie dialogu międzynarodowego

Dlaczego można i należy podejmować problem międzykulturowości i dialogu międzykulturowego w kontekście prawnym i instytucjonalnym?

Za takim podejściem przemawia fakt, że bardzo często w dyskusjach na temat społeczeństwa wielokulturowego występują odniesienia do tego kontekstu z trzech głównych przyczyn:

- w większości krajów europejskich w debacie na temat tożsamości narodowej centralne miejsce zajmują reformy polityk imigracyjnych, przyznawania obywatelstwa i procedur integracyjnych, co znajduje wyraz w aktualnym ustawodawstwie; 
- gromadzenie środków instytucjonalnych, zwłaszcza budżetowych i subwencji zarządzanych przez wyspecjalizowane organizmy i personel zajmujący się sprawami imigrantów i mniejszości, stało się istotnym zadaniem państw oraz władz samorządowych zarówno w zakresie polityk edukacyjnych, zatrudnienia, jak i mieszkalnictwa;

- rola prawodawstwa ma zasadnicze znaczenie w ochronie tych osób, które najdotkliwiej doświadczają marginalizacji: jest instrumentem uznania ich podstawowych wolności oraz ich godności.

Perspektywa prawna i instytucjonalna pozwala ustalić, jaka jest oficjalna polityka władz publicznych oraz dominujący dyskurs w stosunku do tzw. mniejszości. Polityka ta określa formy ekspresji i uczestnictwa mniejszości w życiu narodowym, sposoby walki z dyskryminacją rasową, etniczną i religijną oraz model integracji, który powinien służyć spójności społecznej, jak też jego ograniczenia i dysfunkcje. Poza tym prawo odzwierciedla koncepcje odnośnie do tożsamości i integralności każdego państwa. Prawo i polityki publiczne mogą wręcz stanowić płaszczyznę refleksji na temat fundamentów, na jakich oparty jest system demokracji, oraz sposobów rozwiązywania problemów segregacji społecznej i dyskryminacji. Prawo umożliwia ustalenie naruszeń podstawowych wolności oraz wskazuje konkretne instrumenty, za pomocą których należy je zwalczać1.

Powyższe uzasadnienie można również odnieść do instytucji międzynarodowych. Traktaty, konwencje, porozumienia są zasadniczymi elementami międzynarodowego porządku prawnego, albowiem obowiązują państwa, które je ratyfikowały. Państwo, które składa podpis pod traktatem lub konwencją, deklaruje wolę polityczną i zdolność realizacji przyjętych na siebie zobowiązań. Ustawy, polityki i praktyki krajowe muszą być zgodne z zawartymi porozumieniami.

Na poziomie międzynarodowym, a w szczególności na poziomie Rady Europy i Unii Europejskiej, funkcjonują mechanizmy kontroli umożliwiające śledzenie, ewaluację i sankcjonowanie realizacji przyjętych zobowiązań. Rola tych organizacji w promowaniu edukacji międzykulturowej i kreowaniu dialogu międzykulturowego jest kluczowa, albowiem zalecają one reorientacje tradycyjnych podejść do różnorodności kulturowej, etnicznej, językowej i religijnej oraz promują wizję społeczeństw bardziej demokratycznych, w których filozofia praw człowieka umożliwia transcendencję partykularyzmów

1 J. Costa-Lascoux: Le multiculturalisme et les institutions. W: C. Camilleri (red.): Différénce et cultures en Europe. Conseil de l'Europe 1995, s. 168 i n. 
narodowych. W tym zakresie szczególne znaczenie ma działalność Rady Europy, która wypracowała wiele instrumentów zawierających odniesienia do edukacji międzykulturowej i dialogu międzykulturowego: konwencje, rekomendacje, rezolucje, deklaracje, „karty”.

Rada Europy podejmuje kwestie różnorodności kulturowej i pluralizmu w wielu deklaracjach, m.in. w deklaracji europejskich ministrów kultury w 1990 roku zatytułowanej Społeczeństwo wielokulturowe i europejska tożsamość kulturowa oraz w Deklaracji w sprawie różnorodności kulturowej, przyjętej przez Komitet Ministrów w 2000 roku². Obydwa dokumenty podkreślają fakt, że kultura europejska jest rezultatem różnorodności i żywotności różnych kultur, na poziomie krajowym, regionalnym i lokalnym, lecz również otwartości na dorobek duchowy, intelektualny i artystyczny reszty świata. Narody Europy mają więc obowiązek ochraniania i promowania tej różnorodności, która jest niezbędna dla harmonijnego funkcjonowania społeczeństw.

Wyzwanie polegające na godzeniu różnorodności kulturowej i spójności społecznej (w sensie możliwie najszerszej integracji społecznej) z biegiem lat stawało się coraz bardziej fundamentalne w związku z procesami globalizacji, posługiwaniem się nowymi technologami informacji, nasileniem się migracji oraz zmianą granic narodowych, zwłaszcza po wydarzeniach, które zmieniły bieg historii europejskiej, poczynając od przełomu lat 80. i 90. ubiegłego stulecia.

Rada Europy przedefiniowała więc swoje struktury i polityki. Ich główne założenia zostały nakreślone podczas kolejnych szczytów szefów państw i rządów: w Wiedniu w 1993 roku ochrona mniejszości narodowych znalazła się w centrum polityki Rady Europy dotyczącej różnorodności kulturowej i edukacji oraz nauczania historii, praw człowieka i poszanowania różnorodności kulturowej. Ten ostatni aspekt został pogłębiony podczas drugiego Szczytu w Strasburgu w 1997 roku $^{3}$. Zasady zawarte w ww. deklaracjach zna-

2 Déclaration "Société multiculturelle et identite culturelle européene", adoptée par les ministres européens responsables des affaires culturelles, Palerme, 25-26 avril 1990; Déclaration sur la diversiée culturelle, adoptée par le Comité des Ministres le 7 décembre 2000.

3 Délaration de Vienne, adoptée lors du 1er Sommet des chefs d'Etats et de gouvernement des Etats membres du Conseil de l'Europe, Vienne, octobre 1993. Déclaration sur l'éducation interculturelle dans le nouveau contexte européen, adoptée par la Conférence permanente des ministres européens de l'Education, Athènes, novembre 2003. 
lazły swoje odzwierciedlenie w dokumentach Stałej Konferencji Europejskich Ministrów Edukacji, m.in. w deklaracji ateńskiej w 2003 roku zatytułowanej Edukacja międzykulturowa w nowym kontekście europejskim, w której edukacja międzykulturowa została ściśle powiązana z doskonaleniem jakości edukacji jako odpowiedź na wyzwanie, jakie stwarza różnorodność społeczeństw europejskich. Uczestnicy konferencji zwrócili uwagę na potrzebę wzmocnienia edukacji międzykulturowej oraz zarządzania różnorodnością poprzez programy kształcenia ustawicznego kadry pedagogicznej. Deklaracja zawiera szereg zaleceń dla państw członkowskich, np. wprowadzanie do programów kształcenia wstępnego i ustawicznego nauczycieli problematyki niedyskryminacji, pluralizmu i sprawiedliwości; rozwijanie strategii pedagogicznych i metod pracy, które przygotowują nauczycieli do zarządzania nowymi sytuacjami, powstającymi w szkołach w związku z dyskryminacją, rasizmem, ksenofobią, seksizmem i marginalizacją.

Rada Europy przyjmuje często rekomendacje. Nie mają one charakteru obligatoryjnego, lecz są wyrazem uzgodnień międzynarodowych: zachęcają państwa członkowskie do podejmowania działań w określonej dziedzinie, według zasad i kryteriów wymienionych w danej rekomendacji. Rekomendacje są przygotowywane i redagowane przez przedstawicieli państw członkowskich z udziałem Sekretariatu RE i stają się oficjalnym dokumentem po przyjęciu przez Komitet Ministrów lub Zgromadzenie Parlamentarne. W konsekwencji, jeśli państwa chcą wywiązywać się ze swoich zobowiązań wobec Organizacji, muszą podjąć refleksję nad środkami realizacji rekomendacji na poziomie krajowym oraz składać odpowiednie sprawozdania. Rekomendacje Zgromadzenia Parlamentarnego są kierowane do parlamentów narodowych, natomiast rekomendacje przyjęte przez Komitet Ministrów są przekazywane bezpośrednio do rządów. Kongres Władz Lokalnych i Regionalnych Rady Europy oraz Europejska Komisja przeciw Rasizmowi i Nietolerancji również generują rekomendacje.

$\mathrm{Z}$ licznych rekomendacji można wymienić Rekomendację Komitetu Ministrów w sprawie przygotowania nauczycieli do edukacji na rzecz międzykulturowego zrozumienia, zwłaszcza w kontekście migracji (1984)4. Stwierdza się w niej, że wielokulturowość społeczeństw europejskich jest zjawiskiem nieodwracalnym i stałym, globalnie pozytywnym przede wszystkim, ponieważ umożliwia zacieśnienie więzi między Europą i innymi częściami świata.

4 Recommandation (84) 18 sur la formation des enseignants à une éducation pour la compréhension interculturelle, notamment dans un contexte de migration. 
Różnorodność kulturowa, zwłaszcza związana z kontekstem migracyjnym, stanowi bogactwo, pod warunkiem promowania polityk edukacyjnych, które sprzyjają otwartości umysłu i wzajemnemu zrozumieniu.

Komitet Ministrów zalecił włączenie wymiaru międzykulturowego oraz zrozumienia między różnymi wspólnotami do kształcenia wstępnego i ustawicznego nauczycieli, aby mogli rozwijać odpowiednie kompetencje. Dokument ten wskazuje na związek edukacji międzykulturowej i spójności społecznej ${ }^{5}$. Rekomendacja z 2008 roku Komitetu Ministrów uznaje zdolność do zarządzania różnorodnością za szczególnie ważną kompetencję nie tylko nauczycieli, lecz wszystkich osób zawodowo związanych z dziećmi. Rekomendacja zaleca obowiązkowe nabywanie kompetencji międzykulturowych zarówno w ramach programów kształcenia wstępnego, jak i ustawicznego oraz organizację doradztwa i nadzoru wewnętrznego i zewnętrznego jako wsparcie dla osób związanych zawodowo z problematyką międzykulturowości.

Inne rekomendacje odnoszą się do polityk lingwistycznych, nauczania historii (która powinna sprzyjać wzajemnemu zrozumieniu, tolerancji, zaufaniu między jednostkami i narodami, lecz która może również być czynnikiem podziałów, przemocy i nietolerancji), różnorodności religijnej, ochrony różnych mniejszości, równości płci w dziedzinie edukacji.

Odnotować należy również odniesienia do edukacji międzykulturowej w Karcie Rady Europy w sprawie edukacji dla demokratycznego obywatelstwa i edukacji dla praw człowieka przyjętej w ramach Rekomendacji Komitetu Ministrów (2010 rok) ${ }^{6}$.

Istotę edukacji dla demokratycznego obywatelstwa i edukacji dla praw człowieka Karta upatruje w uczeniu się wspólnego życia w społeczeństwie demokratycznym i wielokulturowym, w nabywaniu wiedzy i kompetencji niezbędnych dla umacniania spójności społecznej, w docenianiu różnorodności, zwłaszcza wyznaniowych i etnicznych, w rozwiązywaniu nieporozu-

5 Spójność społeczna w ujęciu Rady Europy oznacza „zdolność danego społeczeństwa do zapewnienia dobrobytu dla wszystkich jego członków, do redukowania jak tylko można różnic oraz unikania polaryzacji. Społeczeństwo spójne jest solidarną wspólnotą wolnych jednostek dążących do wspólnego celu za pomocą demokratycznych środków". Assemblée parlementaire du Conseil de l'Europe, 13e session, session de printemps, Strasbourg, 27 et 28 mars 2007.

6 Charte du Cinseil de l'Europe sur l'éducation à la citoyenneté démocratique et l'éducation aux droits de l'homme. Recommandation CM/Rec(2010)7 adoptée par le Comité des Ministres le 11 mais 2010 et exposé des motifs, Conseil de l'Europe, Strasbourg 2011. 
mień i konfliktów na drodze pokojowej z poszanowaniem praw każdej jednostki oraz w zwalczaniu wszelkich form dyskryminacji i przemocy.

Komitet zalecił rządom państw członkowskich zaznajomienie edukacyjnych i młodzieżowych władz krajowych z postanowieniami Karty, przekazanie rekomendacji państwom sygnatariuszom Europejskiej Konwencji Kulturalnej niebędących członkami Rady Europy, jak również organizacjom międzynarodowym.

W praktyce międzynarodowej termin „Karta” oznacza bądź instrument prawny wiążący, czego najbardziej znanym przykładem jest Karta Narodów Zjednoczonych, jak też instrument nieobligatoryjny, jak np. Karta Praw Podstawowych Unii Europejskiej w czasie jej przyjęcia w 2000 roku (na mocy Traktatu Lizbońskiego z 2005 roku większość państw członkowskich Unii Europejskiej uznała obowiązujący charakter ww. Karty. W. Brytania i Polska przystąpiły do Karty w ograniczonym zakresie poprzez przyjęcie dodatkowego protokołu będącego częścią Traktatu Lizbońskiego).

W praktyce Rady Europy spotykamy tego typu instrument również, bądź jako wiążący, np. Europejska Karta socjalna z 1961 roku, znowelizowana w roku 1996, oraz jako niewiążący, czego przykładem jest Europejska karta uczestnictwa młodzieży w życiu lokalnym i regionalnym. Gdy określona problematyka jest ujęta w formie karty, oznacza to dążenie do przedstawienia dokumentu o większym znaczeniu niż wcześniej przyjęte w danej dziedzinie przez Radę Europy. Generalnie, dokument o nazwie „karta” podkreśla związek z aktami historycznymi dotyczącymi kwestii praw i wolności, np. angielską Magna Charta Libertatum (1215 rok).

Należy stwierdzić, że cele edukacji międzykulturowej są klarownie określone w dokumentach Rady Europy, wskazują bowiem w jaki sposób decydenci polityczni, lecz również wszyscy aktorzy systemu edukacyjnego i ogół obywateli powinni przyczyniać się do zarządzania różnorodnością i jej waloryzacji.

Podejście Rady Europy do problematyki różnorodności i edukacji międzykulturowej wiąże się z działaniami i inicjatywami tej organizacji na rzecz dialogu międzykulturowego.

Społeczeństwa europejskie, ich środowisko kulturowe podlegają szybkiej ewolucji. Coraz większa różnorodność kulturowa zawiera aspekty ekonomiczne, społeczne i polityczne, które wymagają adekwatnych działań, albo-

7 Charte sociale européenne (STE nr 35) 1961; Charte sociale euroéeenne (revisée) (STE nr 163) 1996. 
wiem niosą ze sobą nowe wyzwania polityczne i społeczne. Ta różnorodność jest często źródłem nietolerancji, stereotypów, rasizmu, ksenofobii, dyskryminacji i przemocy, stając się zagrożeniem dla pokojowego współżycia wspólnot lokalnych i narodowych.

Dialog między kulturami powinien, w przekonaniu Rady Europy, stanowić antidotum na ww. patologie, zasadniczy sposób demokratycznego porozumiewania się, uczyć, jak żyć wspólnie w sposób pokojowy i konstruktywny w wielokulturowym świecie. Rada Europy dokłada więc starań, aby rozwijać dialog międzykulturowy w Europie oraz zacieśniać w tym zakresie współpracę między jej państwami członkowskimi.

W 2005 roku trzeci Szczyt szefów państw i rządów (który miał miejsce w Warszawie) oficjalnie potwierdził, że jedną z głównych misji Organizacji jest promowanie dialogu międzykulturowego (i jego wymiaru religijnego) jako narzędzia promowania otwartości, zrozumienia, pojednania i tolerancji, zapobiegania konfliktom oraz zapewnienia spójności społecznej ${ }^{8}$. To stanowisko zostało szczegółowo przedstawione w Deklaracji z Faro w sprawie strategii Rady Europy na rzecz rozwoju dialogu międzykulturowego, przyjętej przez ministrów kultury w październiku w tym samym roku' ${ }^{9}$ Wymiarowi religijnemu dialogu międzykulturowego były poświęcone konferencje Dialog kultur $i$ wspótpraca międzywyznaniowa w Niżnim Novgorodie (2006 rok) oraz Wymiar religijny dialogu międzykulturowego w Saint-Marin (2007 rok) ${ }^{10}$. Jak wskazują przyjęte tam deklaracje, promowanie dialogu międzykulturowego i międzyreligijnego ma zapewnić lepsze wzajemne zrozumienie kultur, przyczynić się do spójności społecznej oraz stabilności na zasadzie akceptacji Innego. Podkreślono, że wierzący, jak i niewierzący mają równe prawo uczestniczenia w debatach na temat moralnych fundamentów społeczeństwa oraz w forach na rzecz dialogu międzykulturowego. Rada Europy dostrzega również znaczenie dialogu między samymi wspólnotami wyznaniowymi.

8 Déclaration de Varsovie et Plan d'action, adoptés par le Sommet des chrfs d'Etats et de gouvernement des Etats membres du Conseil de l'Europe, Varsovie, mai 2005.

9 Déclaration de Faro sur la Stratégie du Conseil de l'Europe pour le développement du dialogue interculturel, adoptée par la Conférence des Ministres européens responsables des affaires culturelles, Faro/Portugal, octobre 2005.

10 Déclaration finale de la Conférence internationale: Dialogue des cultures et coopération interconfessionnelle. Forum de la Volga; Niżni Novgorod, Fédération de Russie, 7-9 septembre 2006; Déclaration finale de la Conférence européenne sur "La dimension religieuse du dialogue intercultural," Sint-Marin, 23 et 24 avril 2007. 
W dniach 7-9 kwietnia 2011 roku odbyło się w Baku Forum światowe nt. dialogu międzykulturowego pod hasłem „Zjednoczeni dzięki wspólnym wartościom, bogaci dzięki naszej różnorodności kulturowej” przy wsparciu Rady Europy i UNESCO, poświęcone praktycznym i teoretycznym zagadnieniom zarządzania dialogiem międzykulturowym na poziomie światowym.

W 2008 roku państwa członkowskie przyjęły Białą Księgę w sprawie dialogu międzykulturowego „Żyć wspólnie jako równi w godności”11.

„Białe Księgi” są dokumentami wytyczającymi kierunki działań, zawierają ogólne informacje i propozycje akcji w specyficznym obszarze polityki. Sama nazwa i koncepcja białej księgi wywodzi się z praktyki parlamentarnej, zwłaszcza angielskiej pierwszej połowy XX wieku, polegającej na stosowaniu białej oprawy dla tego typu dokumentu, zamiast w tradycyjnym kolorze niebieskim. Rada Europy opublikowała dotychczas tylko trzy białe księgi, a mianowicie: Biata Ksiegę w sprawie ochrony praw człowieka i godności osób chorych psychicznie (2000 rok), Biała Ksiegge w sprawie zasad dotyczacych konsekwencji prawnych filiacji (2003 rok) oraz wspomnianą Biała Ksiege w sprawie dialogu międzykulturowego.

Biała Księga w sprawie dialogu międzykulturowego została przyjęta w 2008 roku przez ministrów spraw zagranicznych państw członkowskich RE podczas 118 sesji i jest uznawana obecnie za dokument referencyjny w kwestiach demokratycznego zarządzania różnorodnością: zarysowuje długofalowe kontury polityki na rzecz dialogu kultur, dostarcza narzędzi analitycznych i metodologicznych oraz norm ułatwiających prowadzenie i promowanie tego dialogu. Jest wynikiem długiego procesu refleksji podjętej w ramach różnych struktur Rady Europy (np. Zgromadzenia Parlamentarnego), jak i konsultacji prowadzonych na szczeblu rządowych ekspertów, przedstawicieli organizacji międzynarodowych, organizacji pozarządowych, przedstawicieli wspólnot etnicznych i religijnych, organizacji imigranckich, kobiecych i młodzieżowych państw członkowskich RE. Jest adresowana do decydentów politycznych, organizacji społecznych, wspólnot religijnych, instytucji edukacyjnych, mediów, partnerów społecznych oraz innych instytucji krajowych i międzynarodowych.

Dokument ten definiuje dialog międzykulturowy jako „proces otwartej i nacechowanej szacunkiem wymiany poglądów między osobami i grupami o różnym pochodzeniu, tradycjach etnicznych, kulturowych, religijnych

11 Conseil de l'Europe, Livre blanc sur le dialogue interculturel „Vivre ensemble dans l'egale dignité, Conseil de l'Europe, Strasbourg 2008. 
i lingwistycznych, w duchu zrozumienia i wzajemnego szacunku. Wolność i zdolność wypowiadania się, lecz również wola i umiejętność słuchania co inni mają do powiedzenia, są jego (dialogu międzykulturowego) niezbędnymi elementami"12.

W jaki sposób dialog międzykulturowy może wpisać się w europejski system praw człowieka i krajowe systemy prawne i polityczne? Innymi słowy, jakie są niezbędne warunki jego powodzenia?

Biała Księga wymienia pięć różnych, lecz współzależnych podejść w działaniach o charakterze politycznym, które stanowią jednocześnie ramy konceptualne dialogu międzykulturowego. Oto one:

Polepszyć demokratyczne zarządzanie różnorodnością kulturową. Punktem wyjścia i celem, jaki należy osiągnąć, aby skutecznie promować dialog międzykulturowy, jest istnienie kultury politycznej waloryzującej różnorodność, zaś kamieniem węgielnym demokratycznego zarządzania różnorodnością kulturową są prawa człowieka i podstawowe wartości, nadrzędność prawa, pluralizm, tolerancja, niedyskryminacja i wzajemny szacunek. Dialog międzykulturowy nie może się rozwijać, jeśli te wstępne warunki nie są spełnione. To pierwsze podejście jest najważniejsze, ponieważ dotyczy ram politycznych, prawnych i społecznych, w których powinna dokonywać się równowaga między różnorodnością i koherencją.

Umacniać demokratyczne obywatelstwo i uczestnictwo. To podejście ma na uwadze systemy interakcji między mniejszością i większością w społeczeństwie, adaptację systemów partycypacji, ich większą elastyczność i otwartość na uczestnictwo wszystkich. Obywatelstwo oznacza prawo, a nawet obowiązek uczestnictwa w życiu społecznym i ekonomicznym, jak również w sprawach publicznych wspólnoty. Wysoki poziom zaufania społecznego i działalność w organizacjach społecznych jest cechą systemu demokratycznego zarządzania opartego na nadrzędności prawa, które umacnia partycypację. Obywatelstwo w drugim znaczeniu to naturalizacja. Przyznawanie obywatelstwa nie należy uzależniać od zrzeczenia się obywatelstwa kraju pochodzenia.

Uczyć się i nauczać kompetencji międzykulturowych. Trzecie podejście wskazuje na potrzebę nabywania, praktykowania i posiadania tych kompetencji w ciągu całego życia. Władze publiczne, szkolnictwo podstawowe,

12 „Livre blanc sur le dialogue interculturel. „Vivre ensemble dans l'egale dignité", s. 6 (strony według wersji elektronicznej: http://www.coe.int/t/dg4/intercultural/ White Paper_Intercultural Dialogue_2_fr.asp). 
średnie i wyższe, pracownicy oświaty, organizacje społeczeństwa obywatelskiego, wspólnoty religijne, media oraz wszystkie inne osoby świadczące usługi edukacyjne, pracujące w różnych kontekstach instytucjonalnych i na różnych poziomach, mogą odegrać w tym zakresie decydującą rolę. Skutecznym medium nabywania kompetencji międzykulturowych i mędzyreligijnych jest edukacja dla demokratycznego obywatelstwa, nauka języków i historii.

Tworzyć przestrzenie dla dialogu międzykulturowego. Czwarte podejście podkreśla, że powodzenie zarządzania międzykulturowego, na wszystkich poziomach, zależy w dużym stopniu od zwielokrotnienia przestrzeni dla dialogu międzykulturowego: przestrzeni fizycznych (jak np. szkoły, kluby młodzieżowe, miejsca kultu religijnego, tereny wypoczynkowe etc.) oraz wirtualnych (np. media). Głównym problemem polityki tzw. multikulturalizmu jest segregacja kultur, brak przestrzeni do interakcji i uczenia się odmienności. W kontekście polityki integracji, która godzi różnorodność kulturową i spójność społeczną, należy zapewnić maksimum wspólnej przestrzeni, sprzyjających warunków do spotkania kultur.

Wzmacniać dialog międzykulturowy w stosunkach międzynarodowych. Mając na uwadze wielorakie i złożone relacje między społeczeństwami europejskimi i nieeuropejskimi oraz ich rządami, promowanie dialogu międzykulturowego powinno dokonywać się na trzech różnych poziomach: w ramach każdego państwa europejskiego, między różnymi kulturami tych państw oraz między Europą a resztą świata. Każdy poziom zarządzania - lokalny, regionalny, krajowy i międzynarodowy - jest odpowiedzialny za spójną politykę dialogu międzykulturowego.

Biała Księga zwraca uwagę na proces dywersyfikacji kulturowej, który nasilił się od kilku dziesięcioleci; podkreśla znaczenie tolerancji, otwartości umysłu w kontekście pluralizmu. Powołując się na stanowisko Europejskiego Trybunału Praw Człowieka, stwierdza, że pluralizm polega na faktycznym uznaniu i poszanowaniu różnorodności oraz dynamiki tradycji kulturowych, tożsamości etnicznych i kulturowych, przekonań religijnych oraz idei i koncepcji artystycznych, literackich i społeczno-ekonomicznych i że harmonijna interakcja między osobami i grupami o różnych tożsamościach jest istotnym czynnikiem spójności społecznej.

Rada Europy, eksponując potrzebę zachowania różnorodności kulturowej, dostrzega równocześnie pułapki i niebezpieczeństwo relatywizmu kulturowego. Relatywizm kulturowy definiowany jest jako niedopuszczalne relatywizowanie poziomu ochrony prawnej w przypadku szkodliwych praktyk 
i wartości tradycyjnych. Często praktyki i wartości tradycyjne są przywoływane, aby zamaskować partykularne interesy lub arbitralne reguły. Nie można powoływać się na tradycje etniczne, kulturowe, religijne lub lingwistyczne, aby uniemożliwiać jednostkom korzystanie z praw człowieka i uczestniczenie w życiu społecznym. Łamanie międzynarodowych norm prawnych, „szkodliwe praktyki tradycyjne", jak przemoc fizyczna wobec kobiet (klitoridektomia), praca dzieci, małżeństwa aranżowane, zbrodnie „w obronie honoru” popełniane na osobach nieprzestrzegających tradycyjnych wartości, nie mogą być usprawiedliwione żadnym kontekstem kulturowym.

Powoływanie się na „prawo do kultury” może być również wykorzystywane przez dominujące wspólnoty kulturowe w celu uzasadnienia bezprawnych praktyk w stosunku do mniejszościowych grup społeczeństwa, uchylania się od krajowych lub międzynarodowych zobowiązań prawnych: „[...] reguły »kultury dominującej « realne lub wyimaginowane nie mogą usprawiedliwiać dyskryminacji, nawoływania do nienawiści lub jakiejkolwiek formy dyskryminacji opartej na religii, rasie, pochodzeniu etnicznym lub innej tożsamości"13.

Tak więc niedopuszczalne jest, aby w demokratycznym społeczeństwie poziom ochrony prawnej osób zależał od ich przynależności kulturowej; innymi słowy, ochrona prawna nie może być „kulturowo relatywna”. Rada Europy i Europejski Trybunał Praw Człowieka nie uznają tego typu „relatywizmu kulturowego". Poza tym Biała Księga podkreśla, że uniwersalne zasady zawarte w prawach i wolnościach promowanych przez Radę Europy stanowią moralny punkt (standard) odniesienia: „Zasady te dostarczają niezbędnych ram dla kultury tolerancji oraz definiują wyraźnie jej granice, zwłaszcza w odniesieniu do wszelkiej formy dyskryminacji oraz przejawów nietolerancji. Tradycje kulturowe zarówno „większościowe”, jak i „mniejszościowe” nie mogą być nadrzędne wobec zasad i wartości zawartych w Europejskiej Konwencji Praw Człowieka oraz w innych instrumentach Rady Europy dotyczących praw cywilnych i politycznych, społecznych, ekonomicznych i kulturowych"14. $\mathrm{Na}$ konieczność przestrzegania tej zasady wskazuje wyraźnie orzecznictwo Eu-

13 „Livre blanc sur le dialogue interculturel. „Vivre ensemble dans l'egale dignité", s. 7 (strony według wersji elektronicznej: http://www.coe.int/t/dg4/intercultural/ White Paper_Intercultural Dialogue_2_fr.asp).

14 „Livre blanc sur le dialogue interculturel. „Vivre ensemble dans l'egale dignité", s. 3 (strony według wersji elektronicznej: http://www.coe.int/t/dg4/intercultural/ White Paper_Intercultural Dialogue_2_fr.asp). 
ropejskiego Trybunału Praw Człowieka ${ }^{15}$. Nadmienić należy, że Europejski Trybunał partycypował w pracach nad Kartą dialogu międzykulturowego.

Wynika z powyższego, że Europejska Konwencja Praw Człowieka i Podstawowych Wolności (EKPC) oraz jej protokoły definiują normy, które determinują aspekty polityczne i prawne dialogu międzykulturowego. Podpisana w 1950 roku (weszła w życie w roku 1953). Konwencja nie była dziełem przypadku. Podobnie jak Powszechna Deklaracja Praw Człowieka, przyjęta w grudniu 1948 roku przez Organizację Narodów Zjednoczonych, była ona wynikiem tragicznych doświadczeń drugiej wojny światowej. Powszechna Deklaracja Praw Człowieka była i pozostaje nadal dokumentem o wielkim znaczeniu moralnym, lecz nie wygenerowała stałego mechanizmu gwarantującego przestrzeganie zobowiązań jej sygnatariuszy. Międzynarodowy Trybunał Sprawiedliwości (MTS) - główny organ sądowy ONZ - rozstrzyga spory wyłącznie między państwami, inne podmioty nie mogą być stronami przed Trybunałem. Członkostwo w ONZ nie oznacza automatycznej zgody państwa na jurysdykcję MTS.

Tymczasem Konwencja takim mechanizmem dysponuje, a jest nim Europejski Trybunał Praw Człowieka (z siedzibą w Strasburgu), który interpretuje i nakazuje stosowanie Konwencji oraz rozpatruje skargi wnoszone przeciw państwom (stronom Konwencji), bądź przez inne państwa (strony Konwencji), bądź przez osoby fizyczne. Konwencja ma zastosowanie do około 800 tys. osób z 47 państw członkowskich Rady Europy, które uznają kompetencje Europejskiego Trybunału Praw Człowieka.

Wprawdzie kraje te, podpisując Konwencję, zobowiązały się przestrzegać i promować prawa człowieka, demokrację i państwo prawa, niemniej różnią się znacząco swoją historią, ustrojem politycznym, religią, ludnością i kulturą. Stosując Konwencję, Trybunał Strasburski dąży do kreowania europejskiego porządku prawnego mającego zastosowanie w odniesieniu do wszystkich 47 państw członkowskich oraz ich mieszkańców (również niebędących ich obywatelami), tj. do wszystkich mniejszości i większości etnicznych, religijnych, lingwistycznych i społecznych, które tworzą społeczeństwa europejskie. Europejska Konwencja Praw Człowieka i Podstawowych Wolności stanowi najważniejszy instrument ochrony praw człowieka i podstawowych wolności na kontynencie europejskim.

15 P. Wiater: Le dialogue interculturel dans le système euroéen de protection des droits de l'homme, Conseil de l'Europe, Strasbourg 2011. 
Nie może więc budzić zdziwienia fakt, że Komisja Europejska rozpoczęła procedurę prawną w sprawie przystąpienia Unii Europejskiej do EKPC. Jej przystąpienie do konwencji stało się możliwe z chwilą wejścia w życie Traktatu Lizbońskiego 1 grudnia 2009 roku, bez konieczności uzyskania członkostwa w Radzie Europy. W ten sposób Europejski Trybunał Praw Człowieka uzyska prawo do kontrolowania aktów instytucji, organów i agencji UE, w tym orzeczeń Europejskiego Trybunału Sprawiedliwości UE (z siedzibą w Luksemburgu), pod względem ich zgodności z przepisami Europejskiej Konwencji Praw Człowieka. Fakt, że stroną konwencji stanie się UE, oznacza również możliwość wnoszenia skargi do Europejskiego Trybunału Praw Człowieka przez osoby fizyczne, które uznają, że stały się ofiarą naruszenia przez UE praw podstawowych.

\section{Bibliografia}

Assemblée parlementaire du Conseil de l'Europe, 13e session, session de printemps, Strasbourg, 27 et 28 mars 2007.

Charte du Cinseil de l'Europe sur l'éducation à la citoyenneté démocratique et l'éducation aux droits de l'homme. Recommandation CM/Rec(2010)7 adoptée par le Comité des Ministres le 11 mais 2010 et exposé des motifs, Conseil de l'Europe, Strasbourg 2011.

Charte sociale européenne (STE nr 35) 1961.

Charte sociale euroéeenne (revisée) (STE nr 163) 1996.

Conseil de l'Europe, Livre blanc sur le dialogue interculturel „Vivre ensemble dans l'egale dignité", Conseil de l'Europe, Strasbourg, 2008.

Costa-Lascoux J.: Le multiculturalisme et les institutions. W: C. Camilleri (red.): Différénce et cultures en Europe. Conseil de l'Europe 1995.

Délaration de Vienne, adoptée lors du 1er Sommet des chefs d'Etats et de gouvernement des Etats membres du Conseil de l'Europe, Vienne, octobre 1993.

Déclaration "Société multiculturelle et identite culturelle européene", adoptée par les ministres européens responsables des affaires culturelles, Palerme, 25-26 avril 1990.

Déclaration sur la diversiée culturelle, adoptée par le Comité des Ministres le 7 décembre 2000. 
Déclaration sur l'éducation interculturelle dans le nouveau contexte européen, adoptée par la Conférence permanente des ministres européens de l'Education, Athènes, novembre 2003.

Déclaration de Faro sur la Stratégie du Conseil de l'Europe pour le développement du dialogue interculturel, adoptée par la Conférence des Ministres européens responsables des affaires culturelles, Faro/Portugal, octobre 2005.

Déclaration de Varsovie et Plan d'action, adoptés par le Sommet des chrfs d'Etats et de gouvernement des Etats membres du Conseil de l'Europe, Varsovie, mai 2005.

Déclaration finale de la Conférence internationale: Dialogue des cultures et coopération interconfessionnelle. Forum de la Volga; Niżni Novgorod, Fédération de Russie, 7-9 septembre 2006.

Déclaration finale de la Conférence européenne sur "La dimension religieuse du dialogue intercultural", Sint-Marin, 23 et 24 avril 2007.

Livre blanc sur le dialogue interculturel. „Vivre ensemble dans l'egale dignite” http://www.coe.int/t/dg4/intercultural/White Paper_Intercultural Dialogue_2_fr.asp).

Recommandation (84) 18 sur la formation des enseignants à une éducation pour la compréhension interculturelle, notamment dans un contexte de migration.

Wiater P.: Le dialogue interculturel dans le système euroéen de protection des droits de l'homme, Conseil de l'Europe, Strasbourg, 2011.

\section{European legal framework for intercultural education and intercultural dialogue}

\section{Summary}

Consideration of the issues of intercultural education and intercultural dialogue in the legal and institutional context can determine the official policy of the state or international organization and the dominant discourse in relation to the so-called minorities. The author focuses on the activities of the Council of Europe, whose role in promoting intercultural education and intercultural dialogue is crucial. The Council of Europe has developed several instruments (conventions, recommendations, resolutions, declarations, charters), which undertake the issues of cultural diversity and pluralism and which promote a vision of more democratic socie- 
ties, where the philosophy of human rights allows for the transcendence of local particularities. Particular attention was paid to the White Paper on International Dialogue "Living Together as Equals in Dignity," now recognized as a reference document on the issues of democratic management of diversity. What was also underlined was the importance of the European Convention on Human Rights and Fundamental Freedoms and the European Court of Human Rights in defining and generating standards that determine the legal and political dimensions of intercultural dialogue.

Key words: intercultural education, intercultural dialogue, Council of Europe, White Paper on International Dialogue

Translated by Wiktor Rabczuk 